\title{
YALE
}

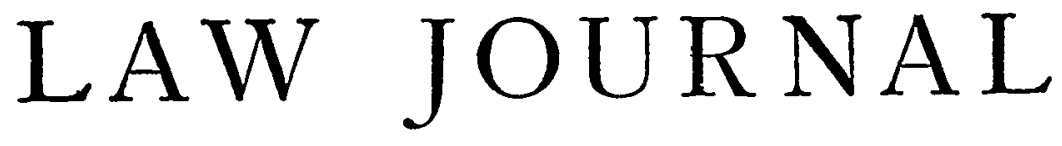

\begin{tabular}{lll}
\hline VOL. III & MARCH, 1894 & No. 4 \\
\hline
\end{tabular}

\section{THE REMEDIAL RIGHTS OF CORPORATIONS AGAINST THEIR DIRECTORS.}

It is the purpose of this article to consider, briefiy, a topic which has occasioned much discussion in the courts, during the last ten or fifteen years; namely, What redress is open to a corporation dissatisfied with a contract entered into with it by a director; and what are the principles which underlie such remedies? We will first suppose a case. A director in a corporation buys certain property, as a mine, a patent right, or a piece of land, paying therefor five thousand dollars. Very soon afterward he disposes of it to the corporation for ten thousand dollars, taking its obligation for said sum; when that obligation matures, the corporation having passed under a new management does not wish to honor the obligation. What may it do? What it might like to do would be to insist that the contract was utterly void, on the ground that a director is absolutely incompetent to deal with his corporation in any matter in which he is personally interested; that therefore the courts should deny him any relief, thus enabling it to retain the fruits of the contract, and, at the same time, avoid payment. May it do this? We think not. Doubtless there are expressions in many decisions which would seem to justify this, as in Port $v$. Russel, 36 Ind. 60; Pickett $v$. School District No. r, 25 Wisconsin 55 r. But the only American case in which such doctrine appears to have been expressly held, as the ground of decision rendered, is that of People v. Township Board, II Michigan 222, where certain persons, authorized to let contracts for the township, them- 
selves bid for, obtained and performed the contract. Being refused payment for services rendered, they appealed to the courts, which refused them assistance. This is manifestly a somewhat extreme case, and the decision, so far as we are aware, has not been followed. Ordinarily such a decision would be highly unjust and inequitable, and the conduct on the part of a director to warrant it must be grossly improper. So it has generally been held that the acceptance of the benefit of the transaction imposes an obligation to assume its burdens, and that therefore, while it would be the undoubted right of the corporation seasonably to rescind such a contract, and tender back the property, a right which would exist in all cases of contracts by a director with a corporation in which he acted as a member of the board, in a matter in which his interest was adverse to that of the company, thus treating the contract as one voidable at its election, yet, if nothing was done in avoidance, the contract would stand. Barr v. N. Y., L. E. \& W. R. R. Co., r25 N. Y. 175 ; Mallory v. Mallory Wheeler Co., 6x Conn. I35; Tryon $v$. White \& Corbin Co., 62 Conn. 171 .

But now suppose the corporation does not desire to rescind, because the contract is beneficial to it as it stands. Though originally bought for five thousand dollars, and sold by its purchaser to the corporation for ten thousand dollars, the property has proved to be worth very much more than even the larger sum. Has the corporation, notwithstanding this, a cause of action against its director? Doubtless it may have under certain circumstances. There are two principles, either of which will support such action, provided the facts warrant the application. The first, which may be called the equitable rule, is this: In all cases where a person is directly or constructively an agent or trustee for other persons, all profits coming into his hands from the business in which he is so employed, belong in equity to his employer, and not to himself. The right of a principal or cestui que trust to undisclosed profits, is wholly independent of the right to rescind the contract, and, in all probability, has its chief value in cases either where the contract cannot be rescinded, and the parties restored to their former situation in reference to the subject matter, or where rescission is not desired by such principal or cestui que trust. He does not desire the contract to be varied. He demands, as an incident of equity and fair dealing attaching to such contract, that his agent or trustee shall hand over any profit clandestinely made by him. Making a vendor return something he ought not to have does not affect the contract. Hence, by affirming it, no right is released not inconsistent with the contract itself. Now, although directors, 
or managing agents of corporations are not trustees in a technical sense, since, unlike those strictly so, they do not hold the legal title to all or any of the property of the corporation, they are often spoken of as trustees, because the relation is in many respects, one of the highest trust and confidence. They are invested with the most extensive powers, and the exercise of such powers demands the utmost good faith to the company, in all transactions. It follows, then, if the director concealed the fact of his own ownership of the property, throwing the corporation off its guard, because inducing the supposition that he was acting, as he was bound to act, in its sole behalf, not endeavoring to perform the impossibility of faithfully serving two masters, himself one, whose interests are in conflict; or, if the property was so desirable for the use of the company that it is fair to be inferred that it was purchased by the director with a view of making a profit on the sale to the corporation, at a time when, if he had acted with an eye singly to their interests, he would have bought it for them directly; then equity, which "considers that as done, which ought to have been done," will regard the original purchase as having been made for the corporation, though the title was taken in the name of the director, and will hold the amount agreed to be paid by the corporation in excess of the sum paid by the director for the property, as damages which may be recouped from the contract price. Erlanger v. New Sombrero Phosphate Co., L.R., 5 Ch. Div. 73; R. R. Co. v. Kelley, 77 Ill. 426; McGourkey v. Tol. \& Ohio R. R. Co., 146 U. S. 536 .

The other principle which the corporation may invoke may be called the legal one. It is the same, or at least so obviously and completely analogors, as to be justly treated as the same, which exists in that class of cases, well known to the law, where a vendor has been guilty of fraud. The purchaser may, if he chooses, confirm the contract, and, nevertheless, sue the vendor for fraud. Cooley on Torts, 589, 59 I. Thus, if, after discovering a shortage in goods, the price is paid, an action lies for the fraud, although the contract may not be disaffirmed. Nauman $v$. Oberle, 90 Mo. 666. Where a partner sold his own goods to a partnership, without the knowledge of his associates, he was held liable to account to them for the profits. Bentley v. Craven, 18 Beav. 75. An interesting case of this character is that of Murray $v$. Jennings, 42 Conn. 9. It was an action for fraud in the exchange of a horse by the defendant for a yoke of oxen, the defendant fraudulently representing the horse as sound, when it was not so. The plaintiff was guilty of no fraud, and would not have made the 
exchange but for the defendant's representations. It was an even exchange, the oxen at the time, were found by the court to be worth $\$$ roo, the horse was worth $\$ 125$, and if sound would have been worth $\$ 225$. The plaintiff who was a woman retained the horse, and claimed to recover this hundred dollars. The defendant's counsel, in his brief, said, "Here is fraud, but no damage. Instead of loss, the plaintiff made $\$ 25$ by the barter." If the plaintiff had returned the horse, she could recover but \$roo. Can she keep it and recover the same? The court said that she could.

If, therefore, in the case supposed, the director used any art or artifice, calculated to deceive and defraud, an action by the corporation, affirming the contract, might be sustained on this ground.

Closely akin, in its legal aspects to the position of a director or managing agent of a corporation, is that of a promoter. This word has been said to be " not a legal, but a business term, usefully summing up, in a single word, a number of business operations, familiar to the commercial world, by which a company is generally brought into existence." Bowen, J., in Whalley Bridge Calico Printing Co. v. Green et al., 28 Wt'y Rep. (Q. B. Div. I880) $35 \mathrm{r}$, 352. In reference to such persons, James, L. J., in New Sombrero Phosphate Co. v. Erlanger,' L. R., 5 Ch. Div. Ir8, said: "It is quite open to a man to buy any property he likes, at any price he likes, with a view, or in the hope, of selling that property to any company that he can get to buy it, if that is the mode in which he intends to dispose of it. A man may buy at any price, and may sell at any price that he can fairly get for it. But that has nothing whatever, as it appears to me, to do with the question in this case, which is, whether a man who has so bought, at a low price, has obtained a higher price, fairly and properly, in accordance with the view which a court of equity takes of such transactions. A promoter is, according to my view of the case, in a fiduciary relation to the company which he promotes, or causes to come into existence. If that promoter has a property which he desires to sell to the company, it is quite open to him to do so, but upon him, as upon any other person in a fiduciary relation, it is incumbent to make full and fair disclosure of his interest and position with respect to that property. I can see no difference in that respect, between a promoter and a trustee, steward or agent."

The law upon the important subject of the rights and liabilities of promoters has probably, up to date, received more consideration in the English courts than in this country, although such cases are getting somewhat frequent in our American reports. 
Mainly, a high standard of integrity and fairness is recognized, and sought to be enforced. In addition to cases already cited, which illustrate the doctrines of this article, chiefly as applied to promoters of corporate enterprises, a few others may be added. Ladywell Mining Co. v. Brooks, L. R., 34 Ch. Div., and on appeal, same case, $35 \mathrm{Ch}$. Div. 400; In re Cape Breton Land Co., L. R., 29 Ch. Div. 795 ; Bagnall v. Carlton, 6 Ch. Div. 385 ; Hichins $v$. Congreve, I Russ \& My. r5o; McElhenny's Appeal, 6r Pa. St. r88; Simons v. Vulcan Oil Co, 61 Pa. St. 202; So. Joplin Land Co. v. Case, 104 Mo. 572 ; Phosphate Sewage Co. v. Hartmont, L. R., 5 Ch. Div. 394: Mission L. \& W. Co. \%. Flash (Cal.), 32 Pac. Rep. 600, and the very late, and still unreported, Connecticut case of Yale Gas Stove Co. v. Jedediah Wilcox et ux. 